\title{
Classification, Nomenclature, and Plant Pathogenic Bacteria - A Clarification
}

\author{
J. M. Young, C. T. Bull, S. H. De Boer, G. Firrao, L. Gardan, G. E. Saddler, D. E. Stead, and Y. Takikawa
}

\begin{abstract}
First author: Landcare Research, Private Bag 92170, Auckland, New Zealand; second author: U.S. Department of Agriculture, 1636 E Alisal Street, Salinas, CA 93905; third author: Center for Animal and Plant Health, 93 Mount Edward Road, Charlottetown, PE C1A 5T1, Canada; fourth author: Dipartimento di Biologia Applicata alla Difesa delle Piante, Universita, via Scienze 208, 33100 Udine, Italy; fifth author: Unité de Pathologie Végétale, INRA, F-49071 Beaucouzé Cedex, France; sixth author: CABI Bioscience, Bakeham Lane, Egham, Surrey TW20 9TY, UK; seventh author: Central Science Laboratory, Ministry of Agriculture, Fisheries and Food, Sand Hutton, York, YO4 1LN, UK; and eighth author: Plant Pathology Laboratory, Shizuoka University, 836 Ohya, Shizuoka 422, Japan.
\end{abstract} Accepted for publication 15 March 2001.

\section{ABSTRACT}

Young, J. M., Bull, C. T., De Boer, S. H., Firrao, G., Gardan, L., Saddler, G. E., Stead, D. E., and Takikawa, Y. 2001. Classification, nomenclature, and plant pathogenic bacteria - A clarification. Phytopathology 91:617-620.

In a recent Letter to the Editor of Phytopathology, proposals were made for endorsement and for rejection of selected names of plant patho- genic Pseudomonas spp. and Xanthomonas spp. We believe that support for, and rejection of, several names was based on misconceptions concerning the Approved Lists of Bacterial Names and entails misinterpretations of several Rules of the International Code of Nomenclature of Bacteria. This letter aims to clarify those misconceptions and misinterpretations.
In a Letter to the Editor, endorsed by the Bacteriology Committee of the American Phytopathological Society, Schaad et al. (14) proposed solutions to a number of apparent problems created by revisions in classification of plant pathogenic bacteria. There are three issues connected with the proposals of Schaad et al. (14): (i) the substitution of earlier species names in preference to recent proposals; (ii) suggestion of a "transitional" species to accommodate current and future xanthomonad pathovars that cannot accurately be allocated to species; and (iii) the rejection of species names recently proposed in the scientific literature. In this expression of the Taxonomy Committee on Plant Pathogenic Bacteria of the International Society for Plant Pathology (ISPP Committee), we note that the proposed solutions were based on certain misconceptions concerning the Approved Lists of Bacterial Names (15; the Approved Lists) and were inconsistent with the Rules of the International Code of Nomenclature of Bacteria (12; the Code).

The intention of introducing the Approved Lists was to create a new start for bacterial nomenclature. Names of species were only included in the Approved Lists if there was a validly published name, a description to differentiate the species from other species, and at least one strain available to serve as the nomenclatural type. The Approved Lists were established according to the 1976 revision of the International Code of Nomenclature of Bacteria (11). This stated that "after 1 January $1980, \ldots$. names .... not included in the approved lists will have no further standing in nomenclature" and "will thus be available for reuse in the naming of new taxa" (4). Notwithstanding their reference to Dye et al. (4) and to Lapage et al. (10), who expressed matters in a similar way, Schaad et al. (14) assumed that nonvalidated species names published before 1980 continued to have a claim to priority.

Corresponding author: J. M. Young; E-mail address: youngj@landcare.cri.nz

* The $e$-Xtra logo stands for "electronic extra" and indicates the HTML abstract available on-line contains supplemental material not included in the print edition. On-line version contains a link to the Taxonomy Committee on Plant Pathogenic Bacteria of the International Society for Plant Pathology.

Publication no. P-2001-0507-020

(C) 2001 The American Phytopathological Society
Since the development of the Approved Lists, some authors evidently assume that the latest reclassification and nomenclatural revision is invariably the most preferable. Although the Approved Lists may have affected the closest correspondence between the best classification and best nomenclature, as was then known, the nomenclature was less than perfect. Since 1980, there have been many revisions, some of which, though sound, were incomplete. Other reclassifications, sometimes leading to comprehensive nomenclatural revisions, may be unsound. Whatever the basis for reclassification, it is essential that means for strain identification is provided if such classifications are to be used routinely by bacteriologists $(17,25)$. Schaad et al. (14) correctly noted that nomenclatural proposals, including those published in the International Journal of Systematic Bacteriology (now the International Journal of Systematic and Evolutionary Microbiology [IJSEM]), are not always the most suitable for some applications, and therefore, that it is for individual bacteriologists to choose classifications and nomenclature that best serve their purposes. Although the Code formed the basis upon which Schaad et al. (14) made their proposals for "acceptance" and "rejection" in relation to plant pathogenic Pseudomonas spp. and Xanthomonas spp., in several of their cases, their interpretation of the Code was incorrect.

Earlier species names. Schaad et al. (14) proposed substitution of X. exitiosa for X. vesicatoria. Originally, Doidge (2) gave the name Bacterium vesicatorium to a pathogen of tomato, and then Gardner and Kendrick (7) named a bacterium causing the same type of symptoms B. exitiosum. However, Gardner and Kendrick (8) concluded that $B$. exitiosum was a synonym of the earlier named pathogen, $B$. vesicatorium, that was subsequently named $X$. campestris pv. vesicatoria (Doidge 1920) Dye 1978, and then $X$. vesicatoria (ex Doidge 1920) Vauterin et al. 1995. In the course of recent studies on $X$. vesicatoria and on strains that Vauterin et al. (18) identified as $X$. axonopodis pv. vesicatoria, it was noted that those identified as $X$. vesicatoria exhibited potent amylolytic properties previously associated with $B$. exitiosum, but that strains of $X$. axonopodis pv. vesicatoria lacked this characteristic (9). Because Gardner and Kendrick (7) reported amylolytic activity in 
their description of B. exitiosum and Doidge (3) reported absence in her description of B. vesicatorium, Schaad et al. (14) proposed revival of the name $X$. exitiosa and its substitution for $X$. vesicatoria. However, according to Rule 27 of the Code, validly published names must meet three criteria: (i) be proposed formally and published in IJSEM; (ii) have a valid description of the taxon or reference to previously published description; and (iii) have a type strain designated for the taxon. None of these criteria were met by Schaad et al. in their proposal of $X$. exitiosa. As a revived name, priority of $X$. exitiosa would date from publication in IJSEM (Rule 28a), but no publication of this name in IJSEM has been made. As matters stand, X. vesicatoria (ex Doidge 1920) Vauterin et al. 1995, is a name validly published according to the Code, whereas $X$. exitiosa as proposed by Schaad et al. (14) is illegitimate (Rule 27). Furthermore, this name is applied to a taxon containing a nomenclatural type with a valid name, $X$. vesicatoria, which Schaad et al. (14) ought to have adopted (Rule 51b). Part of their argument entailed appeal to Rule 12b, which applies to epithets for taxa at the same rank. For the reasons given below, this Rule is inappropriately applied when considering the status of $X$. vesicatoria as species and pathovar. The proper course of action for N. W. Schaad and his colleagues would have been to present the matter, as a Request for an Opinion, to the Judicial Commission of the International Committee on Systematic Bacteriology (ICSB) with a proposal that $X$. exitiosa take precedence over $X$. vesicatoria. For completeness and to avoid confusion, they might also have proposed a new description, with a new type strain for $X$. vesicatoria, as they intended its use, for the taxon containing nonamylolytic strains.

Vauterin et al. (18) included pathovar juglandis as X. arboricola pv. juglandis and pathovar hederae as X. hortorum pv. hederae. X. juglandis was originally named by Pierce (13), and $X$. hederae was originally named by Arnaud (1), but these were not included in the Approved Lists. Schaad et al. (14) proposed that the two species names, $X$. juglandis and $X$. hederae, be reinstated with priority as the basonyms. Schaad et al. (14) believed that these names took precedence over X. arboricola Vauterin et al. 1995, and $X$. hortorum Vauterin et al. 1995, because the specific epithets, juglandis and hederae, were published earlier and should therefore have priority. As noted, pathovar names juglandis and hederae have no standing in the formal nomenclature of the Code and the proposals of $X$. arboricola and $X$. hortorum by Vauterin et al. (18) are in conformity with the Code (Rule 27). The proposals of $X$. juglandis and $X$. hederae are not valid because no descriptions or type strains were proposed, nor was reference made to earlier publications (Rule 27). Although Schaad et al. (14) acknowledged the need for formal proposals with descriptions and type strains, they did not provide them in these cases. As well, and more importantly, these names are applied to the validly published taxa $X$. arboricola and $X$. hortorum, which take priority because they have been legitimately published (Rule 51b). Rule 24a states that, "Those names validly published prior to 1 January 1980 but not included in the Approved Lists have no further standing in nomenclature" and "are thus available for reuse in the naming of new taxa." Schaad et al. (14) were therefore mistaken when they invoked Rule 24 as justifying the reinstatement of species based on the original publication of names and of determining priority based on the old authority. If they wish to substitute the names juglandis and hederae for X. arboricola and X. hortorum, then the proper course is to make a Request for an Opinion to the ICSB Judicial Commission. However, Rule 55 makes it clear that a name cannot be replaced merely because it is inappropriate or disagreeable, a chosen name is preferable, or a chosen name is better known.

The application of descriptive names to taxa, particularly the use of host names for pathogens, has always been a source of confusion (20). Even for pathovars, the host from which the pathogen was first isolated may only reflect part of the host range. The use of nondescriptive names reduces the likelihood of such confusion. Vauterin et al. (18) were not acting improperly in choosing new names for their species as Schaad et al. (14) claimed. Indeed, they avoided the obvious confusion that would have been caused if species names are considered to imply a particular host range (25).

Schaad et al. (14) found the application of the same pathogen name (e.g., vitians) in different taxonomic positions confusing. This situation is analogous to that where species with the same name in different genera are reclassified into the same genus (homonymy) and is covered by the Rules (34b, 41a, and 51b). They were incorrect in invoking Rule $12 \mathrm{~b}$ to suggest that the same name cannot be used for two different pathogens in the different species. There is no inconsistency in terms of the Code or Standards for Naming Pathovars (described below) in a pathogenic species having a particular epithet (e.g., X. populi [ex Ridé 1958] Ridé and Ridé 1992) and the same name being applied to a pathovar in another species (e.g., X. campestris pv. populi De Kam 1984). A problem, analogous to that covered by the Code described previously, is likely to arise if, for example, pv. populi is elevated to species rank or is reclassified in X. populi. In such a case, the pathovar name must give way to taxonomic names at higher levels regulated by the Code (4). In both these cases, as for species under the Code, the pathovar would need to be renamed.

Many names of plant pathogens were applied to bacterial populations that could not be classified as species and, therefore, were not included in the Approved Lists at the time because adequate data were lacking $(23,24)$. These pathogens were therefore given infra-subspecific status as pathovars within valid species. Although pathovar nomenclature is referred to in the Code (Rule 17 and Appendix 10; 12) because it is applied at the infra-subspecific level, it is not governed by the Rules of the Code. However, the ISPP Committee provided International Standards for Naming Pathovars $(4,22)$ to give guidance to plant pathologists and other bacteriologists who wished to maintain an ordered nomenclature for plant pathogenic bacteria. It was understood that there would be revisions of bacterial classification and that some pathovars would be reinstated as species and some pathovars would be reallocated to other species. Furthermore, it was widely recognized that reinstatement of pathovar names to designate a species in other than their original context could cause problems (4). In the introduction to the amended version of the Approved Lists, Skerman et al. (16) noted that the Code did not provide for the protection of pathovars but urged the conservation of these names by taxonomists. The objections to the application of pathovars made by Vauterin et al. (19) have been answered elsewhere (25). Claims that pathovar names are "temporary" (14) or that they would be "automatically [our italics] elevated to their original proper species rank once appropriate phenotypic and genetic data were obtained and validly published" (14) have little validity. Classification of pathogens since 1980 suggests that although some pathovars may be reinstated as species, many will remain as subpopulations within species. We note that plant pathogenicity occurs because some populations of bacteria have particular gene complexes that give them such specific capabilities. However, these genes are distributed in taxa, which may be well defined as species or subspecies, or different complexes may be present in the same species, distinguishable only as pathovars. It is unlikely, and we should have no expectation of the inevitability, that all or even most pathogenic species named in the past will be reinstated.

Transitional names. Schaad et al. (14) noted that one important consequence of the incomplete revision of Xanthomonas by Vauterin et al. (18) was that many unexamined pathovars remained within $X$. campestris (Pammel 1895) Dowson 1939 sensu lato, although $X$. campestris sensu stricto may be applied to pathovars with host ranges in the Cruciferae (and Plantaginaceae). Furthermore, X. axonopodis Starr \& Garcés 1950 emend. Vauterin et al. 1995, now containing many pathovars, is not well circum- 
scribed in phenotypic and genomic terms and, therefore, strains cannot readily be identified in relation to this species and to $X$. campestris sensu lato. Thus, strains of novel pathovars can only be allocated to their appropriate species with difficulty, perhaps relying solely on DNA-DNA reassociation studies for identification (19). As a solution to this problem, Schaad et al. (14) suggested that a new species be established, X. phyllovora, "an artificial neutral taxon as a repository for all pathovars that are inadequately described. This taxon should be reserved for current and future xanthomonads whose descriptions are inadequate for further classification but cause important plant diseases." One objection to this suggestion is that there is no provision for "repository" species in the Code. The species X. phyllovora would necessarily be published without a type strain or genomic comparison, or phenotypic description in the sense understood in bacteriology. It would therefore contravene Rule 27 of the Code, which requires that species names be published in IJSEM with a description and type strain. As such, it would almost inevitably not be considered a validly published name if the question was presented to the ICSB Judicial Commission.

This problem appears to apply particularly to pathovars in Xanthomonas and poses a difficulty for pathologists in developing the nomenclature of pathogens (21). The solution proposed by Vauterin et al. (18) was that pathovars be recognized as belonging to the genus Xanthomonas without allocation to any particular species. Another alternative is that novel pathovars continue to be allocated to $X$. campestris sensu lato. This problem is an important one that cannot be addressed in detail here. The ISPP Committee welcomes discussion of this topic which can be submitted directly to any of its members or to the ISPP website.

Gardan et al. (5) proposed the reinstatement of the species $P$. savastanoi on the basis of their genomic and phenotypic comparison of strains, including the type and pathotype strains of $P$. syringae and $P$. syringae pv. savastanoi. Genomic and phenotypic data were provided to show that strains producing parenchymatous galls and wartlike excrescences on olive, ash, oleander, and other hosts identified as $P$. syringae pv. savastanoi formed a taxon distinct from $P$. syringae pv. syringae and most $P$. syringae pathovars. Because the pathotype strains of $P$. syringae pvs. glycinea and phaseolicola showed high levels of DNA-DNA reassociation with $P$. savastanoi, they also proposed inclusion of these pathovars in the new species. Because type and pathotype strains are the name-bearing strains for nomenclatural purposes (20), their proposal was justified $(21,25)$, although Schaad et al. (14) are not compelled to use it. Subsequently, Gardan et al. (6) have shown that the relationships of $P$. syringae sensu lato and $P$. savastanoi sensu lato are more complex than was indicated in the earlier work. For instance, $P$ amygdali may take priority over $P$. savastanoi, which could be a junior synonym. Recognizing the complexities involved in reclassification, revision with a formal nomenclature may be delayed until more work is done (6). Schaad et al. (14) criticized the earlier work as incomplete, but it was elaborated in the later paper (6) to which they referred.

Rejection of species names. The revision of Xanthomonas by Vauterin et al. (18) involved the proposal of 14 new species. If Vauterin et al. (18) had made these proposals in separate publiccations, then it might have been more obvious that some species were perhaps better supported than other species and acceptance of each species could be based upon its perceived merit. Schaad et al. (14) were correct in noting that these were proposals of names expressing a particular classification, which may or may not be preferred by bacteriologists, according to their choice. However, rejection of the species X. bromi, X. codiaei, X. melonis, X. sacchari, $X$. theicola, $X$. translucens, and $X$. vasicola requires more explanation than is provided (14). Dislike of these names is not an acceptable basis for rejection (Rule 56), which is the prerogative of the ICSB Judicial Commission following a Request for an Opinion. This point has been responded to obliquely by
Vauterin et al. (19). Plant bacteriologists can choose not to use any proposed names of taxa, in favor of earlier nomenclature. It is the position of the ISPP Committee on Taxonomy of Plant Pathogenic Bacteria that bacterial nomenclature is in the hands of every researcher. Attempts to constrain use by instruction, except to ensure conformity to accepted rules, will only slow and obstruct communication.

No doubt, Schaad et al. (14) were well intentioned in their proposal of names, which they believed were more appropriate than those provided in recent publications. However, their misapplications of the International Code of Nomenclature of Bacteria and their proposals of invalid names based upon these misapplications will contribute to the very confusion that they wish to avoid if these names are taken up for use in future literature.

\section{LITERATURE CITED}

1. Arnaud, G. 1920. Une maladie bactérienne du lierre (Hedera helix L.). C. R. Hebd. Seances Acad. Sci. 171:121-122.

2. Doidge, E. M. 1920. A tomato canker. J. Dept. Agric. (Union of South Africa) 1:718-721.

3. Doidge, E. M. 1921. A tomato canker. Ann. Appl. Biol. 7:407-430.

4. Dye, D. W., Bradbury, J. F., Goto, M., Hayward, A. C., Lelliott, R. A., and Schroth, M. N. 1980. International standards for naming pathovars of phytopathogenic bacteria and a list of pathovar names and pathotype strains. Rev. Plant Pathol. 59:153-168.

5. Gardan, L., Bollet, C., Abu Ghorrah, M., Grimont, F., and Grimont, P. A. D. 1992. DNA relatedness among the pathovar strains of Pseudomonas syringae subsp. savastanoi Janse (1982) and proposal of Pseudomonas savastanoi sp. nov. Int. J. Syst. Bacteriol. 42:606-612.

6. Gardan, L., Shafik, H., Belouin, S., Broch, R., Grimont, F., and Grimont, P. A. D. 1999. DNA relatedness among the pathovars of Pseudomonas syringae and description of Pseudomonas tremae sp. nov. and Pseudomonas cannabina sp. nov. (ex Sutic and Dowson 1959). Int. J. Syst. Bacteriol. 49:469-478.

7. Gardner, M. W., and Kendrick, J. B. 1921. Bacterial spot of tomato. J. Agric. Res. 21:123-156.

8. Gardner, M. W., and Kendrick, J. B. 1923. Bacterial spot of tomato and pepper. Phytopathology 13:307-315.

9. Jones, J. B., Bouzar, H., Stall, R. E., Almira, E. C., Roberts, P. D., Bowen, B. W., Sudberry, J., Strickler, P. M., and Chun, J. 2000. Systematic analysis of xanthomonads (Xanthomonas spp.) associated with pepper and tomato lesions. Int. J. Syst. Environ. Microbiol. 50:1211-1219.

10. Lapage, S. P., Clark, W. A., Lessel, E. F., Seeliger, H. P. R., and Sneath, P. H. A. 1973. Proposed revision of the International Code of Nomenclature of Bacteria. Int. J. Syst. Bacteriol. 23:83-108.

11. Lapage, S. P., Sneath, P. H. A., Lessel, E. F., Skerman, V. B. D., Seeliger, H. P. R., and Clark, W. A. (1976 Revision) 1975. International Code of Nomenclature of Bacteria. American Society for Microbiology, Washington, D.C.

12. Lapage, S. P., Sneath, P. H. A., Lessel, E. F., Skerman, V. B. D., Seeliger, H. P. R., and Clark, W. A. 1992. International Code of Nomenclature of Bacteria. P. H. A. Sneath, ed. (1990). American Society for Microbiology, Washington, D.C.

13. Pierce, N. B. 1901. Walnut bacteriosis. Bot. Gaz. 31:272-273.

14. Schaad, N. W., Vidaver, A. K., Lacy, G. H., Rudolph, K., and Jones, J. B. 2000. Evaluation of proposed amended names of several pseudomonads and xanthomonads and recommendations. Phytopathology 90:208-213.

15. Skerman, V. B. D., McGowan, V., and Sneath, P. H. A., eds. 1980. Approved lists of bacterial names. Int. J. Syst. Bacteriol. 30:225-420.

16. Skerman, V. B. D., McGowan, V., and Sneath, P. H. A., eds. 1989. Approved lists of bacterial names. American Society for Microbiology, Washington, D.C.

17. Stackebrandt, E., and Goebel, B. M. 1994. Taxonomic note: A place for DNA-DNA-reassociation and 16S rRNA sequence analysis in the present species definition in bacteriology. Int. J. Syst. Bacteriol. 44:846-849.

18. Vauterin, L., Hoste, B., Kersters, K., and Swings, J. 1995. Reclassification of Xanthomonas. Int. J. Syst. Bacteriol. 45:472-489.

19. Vauterin, L., Rademaker, J., and Swings, J. 2000. Synopsis on the taxonomy of the genus Xanthomonas. Phytopathology 90:677-682.

20. Young, J. M. 2000. Suggestions for avoiding on-going confusion from the Bacteriological Code. Int. J. Syst. Evol. Microbiol. 50:1687-1689.

21. Young, J. M. 2000. Recent systematics developments and implications for plant pathogenic bacteria. Pages 133-160 in: Applied Microbiology Systematics. F. G. Priest and M. Goodfellow, eds. Chapman Hall, London, U.K.

22. Young, J. M., Bradbury, J. F., Davis, R. E., Dickey, R. S., Ercolani, G. 
L., Hayward, A. C., and Vidaver, A. K. 1991. Nomenclatural revisions of plant pathogenic bacteria and list of names 1980-1988. Rev. Plant Pathol. 70:211-221.

23. Young, J. M., Dye, D. W., Bradbury, J. F., Panagopoulos, C. G., and Robbs, C. F. 1978. A proposed nomenclature and classification for plant pathogenic bacteria. N.Z. J. Agric. Res. 21:153-177.

24. Young, J. M., Dye, D. W., Bradbury, J. F., Panagopoulos, C. G., and
Robbs, C. F. 1978. The use of the term "pathovar" in the classification of plant pathogenic bacteria. Pages 359-363 in: Plant Pathogenic Bacteria. Proc. Int. Conf. Plant Pathogenic Bacteria, 6th. Station de Pathologie Végétale et Phytobactériologie, INRA, Angers, France.

25. Young, J. M., Takikawa, Y., Gardan, L., and Stead, D. E. 1992. Changing concepts in the taxonomy of plant pathogenic bacteria. Annu. Rev. Phytopathol. 30:67-105. 